27) Proceedings of the Annual Foresliy Symposium 1995, Sri Lanka, 15-16 December 1995. (Eds. Amorasekera, H $S$ and Banyard, S G). Publishod by Department of Forestry and Emworimental Science, University of Sri Jayewardenspura, Sti Lanks (1996]

\title{
COMMUNITY MANAGEMENT OF LOCAL FORESTS: WOULD IT BE A PROMISING STRATEGY TO SOLVE FOREST MANAGEMENT PROBLEMS IN SRI LANKA
}

\author{
Anoja Wickramasinghe \\ Department of Geography, The University of Peradeniya
}

\begin{abstract}
This paper exammos how nen-forcst sconarios affect the systems of community management of local forests. Field investigations reveal that in practise, a humar-forest interfuce cxists in almost all areas, irrespective of ownership (state or private), status or regulations Examples regarding local management systems, drawn from the fringe communities of Adam's Peak Wildemess, Ritigala Strict Natural Reserve and the Knuckles Range, show that the systems are diverse. In some areas there are well formed social regulations governing the people-forest: interface, while in other areas either no systems exist or they are weak and related to market driven factors. Situations tend to yary even among the communitics living along one fringe. In Ritigala, the commanity managenent systems and social regulations are extremely strong smong indigenous commanities. The cotiesiveness of the conmmunitics influence their group gathering and systems of sharing. The involvement of mdividual families is sidespread in the Knuckies where forcst cultivation has outstanding importance. There are variations along the fringe of the Adan's Peak Wilderness in relation to ethnicity, location, survival systems, and the level of dopendence on forest resources. This suggests. that local community organizations do not exist in all forest peripheries but generation long management practioes, on which community organization could be formod, are an important aspect. It is argued that unless a better understanding of local situations is attaincd, it would not be possible to offer onc blanket recommendation and replicate this for all the forest lands of the country. To accept local mi nagement systems as promising strategies for forest management a broad understanding of their potenttals, rejulations, interests, and organizations should be examined.
\end{abstract}

\section{INTRODUCTION}

The management of forests that stand as isolated islands has been a long standing unsolved problem. Forest management has been an issue debated at an amazing number of international and national gatherings, institutions and also by non- 
Annual:Forestry Symposium, 1995

govemmental organizations, For instance, in its carly stage in 1980, the World Conscrvation strategy (IUCN/UNEP/WWF/,1980) has emphasized the link between conservation and development. After a decade or so in 1991, "Caring for the Earth" published by the IUCN, UNEP and WWF re-emphasized the importance of bringing ecological and cconomic approaches to the use of natural resources. Attempts have boen made to translate these concepts into policies. One outstanding feature with regard to forst management is that the authonty of the state (acquired in the past) has gradually been diluted

From the perspective of sustainable development, the report on the World Conmission on Environment and Development (WCED, 1987) has reiterated the need for integrating environment and economic development to ensure sustainable development. The development of the ideas of utilization or the contribution of cosystems to improving the quality of life can be taken as one of the most important international initiatives of the last two docades. For the better management of forests a number of changes including philosophical, strategical, technological, and institutional bawe been suggested (D'Silva and Kariyawasam (Eds), 1995). Philosophically, there should be a change from the management of trees to the management of complex ecosystems in which people play a central role. Strategically a single silvicultural system cannot be matched with a resource as broad and variable as the tropical forest. Institutionally, forest departments need to be reorganised to meet the new mandates placed on them by society, A point to be noted here is that in reality, the prerequisites for better managenent of forests cannot be generalized without understanding the local contexts and the spatial variations of the interrelated social systems whete changes are perceived to be necessary.

The issues that emerge in translating concepts into actions are rather complex. On the one hand there are the needs for integrating conservation into forest management, and on the other the need to utilize forest resources for improving the lives of people, These issues are more practical than theoretical. The integration of economic goals and people's development needs in forest management in an institutionalized mannor has been more difficult in many field situations than simply changing the perceptions on conservation which occupy the centre of state forest management policies. The simple reason for this is that the communities that could, in practice, connect the two scenarios in a more realistic manner have not been consulted. The possibilities on how a practical transition could be brought about by mutual sharing have not been investigated.

However, the linkages between conservation and development is more complex in practice. For instanee, Gitmour (1994) explains that, "In terms of conservation actions, part of the logic implicit within the sustainable concept (at least for many developing countries) has been to link the conservation of a particular resource with the perceived development needs of the population which is (at least Partly) dependent on that resource for livelihood support". Due to difficulties in translating the concept into practice, Gilmour has shown that arguments supporting it have three

\section{8}


strands; one is the 'altemative livelihood approach' where development nocds of the local people can be met from alternative sources so that their pressure on resources will be lessened. The second deals with the 'economic development approach' where communities cannot be expected to be interested in conservation; and the third is the 'participatory approach' where communities are more likely to agree to conservation initiatives if they can be actively involved in planning and management of resource use and if they can stare the benefits. This suggests that in practical terms changes in policies and legislation dealing simply with forest management alone would not holp maintain those islands of forests for the future

\section{THE MANAGEMENT ISSUES}

The broader perspectives of forest management provide opportunitics for two actors, the 'state' which has sceured legal ownership to the forests for more than a century and 'local communities', who make use of forest resouroes on customary grounds, Formally while the state has maintained its sole authority, the focal communities have maintained their usufruct rights. This implies that two parties have becn involved in forest management without terms of agrocment and communication. The role of state sector has been defined by the respective administration. In Iegal terms and in the context of ownership status, the Forestry Department and the Department of Wildlife Conscrvation are responsible for management. The roles of these sectors are more connected with the administration and protection while informally loeal communities have been engaged in using the resources. This has been the situation prevalent throughout the country irrespective of the legal status of the forests. For instance there are no strict natural reserves completely free from the people's cngagement in using the resources.

However, the forestry sector is in a transitional period and has already focused on diluting its rigid boundaries and the authority over forest management This is to enable people, the unauthorized custodians, to involve themselves in the tasks in a formal manner and in securing their participation. The reasons for diluting boundaries seem to be related to a number of factors. The first is the national commitment towards intermational conventions more than the conecrns over real field situations. The second is the lack of capacity of the state sectors to stop forest denudation and degradation. The third is the ineffectiveness and the inadequate capacity of the state to guard and enforce legislation regarding conservation, and also to contribute towards improving the quality of life of the people and to legalize their socially accepted rights to forest management that the state has not been able to eliminate

When we look at the current situation it can be seen that problems relating to forest management are erucial. The crucial problem is the continued deforestation of the country, in spite of all the institutional arrangements made during the one and a half eenturies or so. The country has lost nearly $50 \%$ of its natural forests during the last five decades. The 1.75 million hectares of natural forest cover bats been reduced to 
about 1.33 million hectares between 1983 and 1992 . While the total forest cover has been reduced from $27 \%$ to $20 \%$, about 54,000 hectares of natural forest are being lost every year. It is not possible for the country to loose the remaining areas of forest which appear as the last remnants of the country's natural wealth. The critical question arising out of this phenomena is whether any strategic adjustment to the state policies which have been introducod in order to exercisc its ownership and administrative authority could solve the critical problems of the continuing deforestation, increasing pressure on forest resources, forest degradation and strinking of the isolated islands of forests. Patterns in the deforestation process clearly show that measures taken by the state sectors have not been able to stop deforestation and reduce external pressures. The alternative in this context should be the locally relevant strategics that could withstand centripetal pressures.

It is in this national and local context, that local communities could be stimulated and invited to become partners for the better management of forests. However, the neod here is not to adopt and include the words of "community enrolment", "community participation" or "community partnership" into the forestry policies in Sri Lanka. These terms have been cntered in the political agenda related to forcstry without having a clear understanding of the spatial situations and complexities. Our national context has shown that the community engagement in forest management is an age old practice continued over generations in spite of all strict legislation. It takes place under a common rights known to people.

Based on the author's previous research investigations (Wickramasinghe, 1990, 1995a, 1995b) the nature of the human-forest interface has been examined. The ways in which such an interface could be built into forestry management and institutionalization need thorough analysis, primarily, the analysis of local situations. Community management of local forests cannot be confined to their cngagement in using forest resources but also includes the managenent of forest ecosystems and also of non-forest lands as an alternative to cater for the increasing demands and to reduce the pressure on forests.

The question we need to ask ourselves is whether community management would be a promising strategy to solve the problems relatod to forest denudation and degradation. It is important to note that provisions have been made in the Forestry Sector Master Plan (1995) to secure community involvement and broaden the management objectives from its conservation and timber production. However, this provision cannot be made operational without relating to local conditions. It is true that there are many successful cases to which we can tum to. For example Gilmour (1998) and Gilmour and Nurse (1991) describe how impoverished communitics in the Nepal Himalayas have taken action to reverse trends of deforestation. An insight into Joint Forest Management in India has boen provided by Saxena (1995). The examples drawn from other areas cannot be replicated. Local cultural and sociocconomic dimensions cannot be ignored. 
Wickramasinghe

This paper is not an attempt to analyze the implications of forest policies in sccuring community engagement, but rather an analytical explanation of the effects of nonforest sccnarios; the livelihoods and customary practices on the community management of forests. The findings summarized here highlight the practical difficulties/opportunities that Sri Lanka's forestry sector will have to take account of if it is to succeed in bringing community involvement to a practical reality. In this paper information is drawn from surveys conducted in 3 geographical arcas, namely,

i. Adam's Peak Wilderness;

ii. The Ritigala Strict Natural Reserve;

iii. The Knuckles Range of Forest.

All 3 areas are mountain forests managed under state ownership, but having different management status. They are surrounded by well established non-forest activities. Gcographically, the Ritigala forest is located in the north-central part of the country, in the dry zone. The Adam's Peak Wildemess is in the central highlands of the wet zone while the Knuckles Range covers rather diverse settings ranging from wet to dry zone conditions. Of these 3, Adam's Peak and Ritigala are of historical and religious importance, while the knuckles Range of forests has been favoured for its potential for producing cardamom. Ritigala forest is a Strict Natural Reserve and managed primarily under the Department of Wildlife Conservation (DWLC) and Iegally excludes people from gathering any products. For the knuckles Range, management plans have been drawn up, while for the Adam's Peak plans are under preparation. The information presentod here has boen gathered on a Rapid Appraisal of the peripherics, questionnaire surveys conducted in a selected number of community clusters and participatory investigations.

\section{COMMUNITIES IN FOREST PERIPHERIES}

Communities living on the fringe of these forests are large in number and vary in terms of their composition, lifestyle, biophysical setting of the non-forest lands on which they depend, indigenous knowledgc, contacts with the forcst, feeling of inheritance and evolutional history and also their interests and concems over forests and their management. What would be the operational definition in regard to communities is important. It cannot be simply used to point to their occupation of the fringe of the respective forests, although gcographical locations are a strong indicator of connections. When the characteristics of compesing member or houscholds living in a geographical arca is taken into consideration on the basis of a large number of aggecgates, some disparities or commonalties may emerge. Quite often, income, wealth, ethnicity, amount of forest based income, experience, concerns and interests tend to vary. Some of these could point to the level of their potential participation in forest management. To be more consistent and broader we need to consider communitics as social systems already existing in forest fringes and located in favourable geographical settings adjoining the forest. This is mainly because, from the perspective of involving them in forest management their shared needs, 
interests and interactions are essential. While geographical locations indicate their village identities, the existing social systerns offer operational focuses.

One advantage of taking communities as social systems is that it allows us to smoothen the variations and deal with interactions. Many variations cannot be overlooked for the sake of promoting their partnership. Another advantage is that it would help avoid disputes that could possibly occur in terms of their differential involvement and help their strength and capacity to act as powerfil social systems, particularly in acting against external threats. In addition, the social systems are needed to form acceptable and viable social regulations that could be made operational under given situations.

\section{TIE SPATIAL VARIATIONS}

There are many spatial variations along the forest fringes both in terms of biophysical and socio-cconomic conditions. In the Adam's Puak Wilderness more prominent differences occur between the north and the south. In the north the communities connected with plantation work differ from those of the traditional village conmunitics living in the south. Their lifestyle, contacts with the forest, income, knowledge, experience, interest and contacts with the forcst differ. The fringe communities in Ritigala have disclosed rather specific features related to their feeling of inheritance. Out of about 20 communities known with their spccific village identities, 4 are heavily coneerned about their customary rights and of the view that the forest is an inherited source of living that has been transferred to them from their ancestors. The interest of the many communities in the fringe of the Knuckles is quite contrasting. They are conecrnod more with the commercial returns that can by made out of forest cultivations. It is related to the economic importance placed on producing cardamom, particularly using the forest micro-environment as a natural advantage. The problems related to leasing out the forest to the better off who come from outside and to some fringe dwellers has not only legislative problems but also acts against executing state policies on conservation. Another problem is that cardamom of the Knuckles is a part of the national cconomy. With the priority given to forest cultivation, the indigenous utilization practices have also suppressed self regeneration and the micro voological conditions, reducing its capacity to support forest resource based activities, and loosing the self confidence of the local communities over the traditionally used non timber forest products and the long term continuity on forest income.

\section{INTERFACE BETWEEN FORESTS AND THE COMMUNITIES}

Forests legally owned by the state are widely used by almost all fringe communities for their multiple products. The usufruct rights of the communities have been maintained without recognition. Although the level of dependence of the households vary, the service functions of the forests are considered to be a condition that helps them to maintain the non-forest activities, primarily agriculture, The forest is equally 
considered as a soturee of multiple products which include a large number of nontimber forest products. For those who depend heavily on agriculture for a living, the forest is the next most important source of survival. The dry zone study in Ritigala shows that throughout the year the forest is a source of survival needs and these include food, fuclwood, mcdicinal products, binding and fencing materials etc. The well marked seasonal nature of other forest products, the varieties sold in the market, primarily Gal-Siyambala (Dialium owideum), Boc Honcy, and Bin-kohomba (Munronia pumila) help smooth the seasonal difficulties in getting an income. The gathering groups are formed for better harvesting within a given periods in which these products are available. When compared with this, the Kunckles shows another type of interaction, that is the tse of forcst lands for cardamom cultivation. Community interaction with the forests for cultivation has resulted in their heavy dependence on cultivated crop in the forest reducing the complementary nature of subsistence farming and non-timber forest products. The concerns of the fringe dwellers over the forest has been driven away from the gathering of non-timber forest products. Collection of medicinal products, binding materials, tapping of Kitul (Caryota turens) for treacle and jaggery means that they have only a marginal interest in the forest. Community interaction under this situation is confined to family involvement in management their own plots of cardamom, thus the collaboration among the families involved is extremely low.

The difference between the north and the south fringes of the Adam's Peak Wilderncss shows that plantation communities use the forest as a free source of fuclwood, some food products, and raw materials to make baskets that they can easily sell in the village matkets in the neighbourhood. However, their contacts are inconsistent and they show hess interest in being involved in managing the forest as part of their survival system. The availability of non-forest based regular work on a wage basis is one of the reasons for their less dependence and concern over management roles. Other contributing factors are their rather weak knowledge on multiple uses and time constraints. The food habits and medicinal practices are not based heavily on the forest resources as found in the indigenous communities in the south. When compared with this situation, the involvenent of the southem fringe communities is strong and the interface is characterized by their dependence on the forest as a source of market and subsistence products, and of indigenous knowledge.

The overall fringe profiles show that community interface with forest cannot be generalized. Although communities are the social systems that share forest and nonforest common resources and partly depend on the forest and characterized by social interactions, all fringe communities do not have the same level of dependence on the forest. Therefore, for stimulating fringe communities for better management of the forest, attempts must be justified from the perspective of their interactions, indigenous practices, dependence and their strength to buffer the forest. 


\section{THE POTENT1AL ROLES OF THE LOCAL COMMUNITIES}

The local communities are the local bodies to be empowered to manage forest resources in collaboration with the state. A joint effort is required whereby both parties must contribute and share responsibilities on mutually acceptable terms. The contribution of local communities to develop buffer zones is one spocific aspect that carnot bo dealt with by state agencies. Their roles can be envisaged in terms of protection, forest regeneration, promoting forest resource based peripheral cconomy. and in supplying forest products. Goographical location has to be considered as an advantageous factor to help protect the forest. It is the communities living in the peripheral areas that detect all the changes in the forest and its boundaries and also outside pressures. All those social systems that keep in touch with the forest are, to date, an untapped resource. The communitics in the peripheral areas are not consulted in preparing and executing plans because forest management has been isolated from other sectors. They are consulted neither on the issues related to forest management nor with regard to non-forest resource management. However, as has been pointed out by the community groups, they are penalized for providing their labour on daily paid basis for the outsiders for resource exploitation, for not reporting the illegal activities happening, and in situations where they report illegal activities they are threatened for reporting the destructive exploitation of the forest resources by influential persons and by some officials. The result is the creation of a rather stressful fecling regarding the management of resources that they are in contact with. The incompatible land uses in the adjoining areas are also due to the undervaluing of the contribution of local communities.

An important question to be asked is bow local communities oould act as a social buffer as partners in forest management whilc continuing as traditional users of forests. In practice, it is the local communities who could play a triple role; the relieving of pressure on the forest; smoothing hostilities between the forest and the non-forcst surroundings; and deflecting destructive exploitation of forcsts (Wickramasinghe, 1995a and 1995c). In fact, in spitc of all legislation introduced so far, the state has not been able to fulfil these roles for the management of depleting forest resources of the country. Problems in the past have not been related to the wcakncss in legislative support, but duc to the exclusion of local communities as local initiatives, and also to policy failures.

The hostilities between the forest and the adjoining non-forest land uses threaten the forcsts by physically pushing back forest boundaries gradually and by exposing the boundaries to various types of destructions. While no fringe communities have been integrated for their potential contributions to forest management, the sectors dealing with non-forest land use have adopted strategies without any conservation interests. For instance, the subsidies given to the farmers to grow tea and cinnamon in the outskirts of the Adam's Peak area, propagation of crops with harmful chemical inputs among the famers in Ritigala, and the stimulation of non-forest uses to grow cardamom in the Kuuckles Range are in fact the hostilities that have been 
Wickramasinghe

unintentionally promoted by the state itself. The communitics that have been formally excluded from the management of local forests have been used by the other sectors. What is needed is to involve local communities as partners in forest management to smoothen the hostilities between the forest and the non-forest land uses. In spite of the variations among communities living along the forest fringes they are in a position to establish green belts for protecting the forest boundaries thus controlling their exposure. Their knowledge on forest species and uses belp regenerate forest spccies in non-forest areas and change the micro-ecological conditions in favour of the forests.

The vegetation profiles drawn from the fortst interior across non-forest fringes show that the species of the forest diminish sharply where land-use is based on seasonal crops. But in some arcas stretches of forest trees are scen outside the forest where people have a great interest of propagating them outside forests. In some pockets the stretches of Bedde-del (Artocarpus nobitis) located in Waleboda area below the southem boundary of the Adam's Peak. Wilderness area, and Palu (Manilkara hexandra), Neem (Azadirachta indica) Moe (Madhuca longifolfa) and Weera (Drypeles sepiaria) Jocated in Kiriyagaswewa, Muriyakadawala in Ritigala smcothen the hostilities in the boundaries.

Another important point is how local communities could cater for the neods for forest products. In the short run they are the providers of non-timber forest products. In the long rum, to meet the increasing demand, they could be motivated to cater for outside forestry needs. This requires their involvement in regenerating forest species in degraded areas of the forests, common reserves in village areas and also in priyate lands. Unless conservation interests are integrated into non-forest sectors, non-forcst lands and forestry widely adopted through community participation, the solutions that could be offered through forestry alone will be rather insignificant. The attempt should be to involve local communities in all the aspects of forestry without drawing boundaries. The exclusion of people from forestry development has deviated from initiatives of local communities and the same have boen employed by the non-forest sectors to achieve their largets and eliminate trees from many areas. For instance, the exhibition of posters placed outside the Ritigala Strict Natural Reserve discloses a clear oppression of local communities of their rights and undervaluing of their potential contributions. Posters show that, "Entry Into the Reserve, Hunting, Setting Fire and Forest Clearing are Completely Prohibited Without Permission". Where these conditions are unenforced and unrealistic in the presence of strong community cornections, we should eather accept their weakness and the strength of the communitics to perform the roles that the state itself could not perform.

\section{QUESTION OF INDIGENOUS KNOWLEDGE}

Indigenous knowiedge has been an area of research and also of intemational concern. in our own local situations this has a number of practical implications. The knowlodge that has evolved over gencrations; transmitted from one generation to 
another through social interaction, and enriched over long periods on pcoples' obscrvations and experience are part of the social systems of the local communities. There is no way for outsiders to penetrate fully into these systems because they are culturally sensitive and some areas of knowicdge systems have already been fragmented due to their exclusion. What is happening is that with the exclusion of people from their management roles, they have become illegal users of state owned resources, so the intention of conserving for the long term benefits has turned into an uncertainty of their status:

It is difficult to generalize the knowledge of local communitics because the whole system is complex due to two factors, One is their direct connection with forest ecosystems which vary spatially, and the other is the variation in the lifestyles among communities. A feature common to all is their knowledge on ethno-botanical aspects of forest species and the spatial variations in forest ccosystems. Based on the two studies direetly related to these aspects - one on anthropogenics related to forest management (Wickramasinghe. 1995a) and the other on the perceptions and knowledge of local communities of biodiversity (Wickramasinghe, 1994) - it is shown that people have an amazing amount of knowledge applicable to fortst management, but so little has been elicited and recorded. Their knowledige on ocosystem variations, species composition, uses as well as the seasonality and forest regeneration is broader than can be extracted from cross sectional studies.

What is important in the long run is to restore the social interaction through which indigenous knowledge is transmittod and retained within the social system. In the absence of a formal delivery system and external involvement, all consultations take place within the communities. As a result, the longer the period that local people have lived and maintained their contacts with the forest the greater is the knowledge acquired by them. The outstanding strength of the forest-people interface in 4 communities in Ritigala who clain to be the descendants of hunting and gathering people the "Veddhas", and also of the southern fringe communities of the Adam's Peak when compared with the plantation communitics who have been settlod within the plantation systems, point to the importance of lesigth of experience. The special features disclosed by them are the harmonious nature of their contacts. This was partly due to the spiritual superiority and holistic nature of the forests which are not considered to be important in the scientific managenent of forests. For the local communitics the importanoe of the forest goes beyond its physical products, and their commitment to manage the forest also bas a definite cultural context.

\section{THE EFFICIENT MANAGEMENT OF FOREST RESOURCES}

The integration of the econonies related to the non-timber forcst products into forcstry policies for better management of forest resources is becoming popular. Not only are the non-timber forest products an integral part of the survival systems but knowledge of non-timber forest products is also part of the wealth of the people who utilize them. The two aspects combined here are related to increasing the 
productivity of the fortsts and their contribution to the local economies and the protecting of resources from over-exploitation through active participation, Although some information is available on the use of non-timber products there is not sufficient information on how people manage the resources in the long term.

The lifestyles of the households and the local economies related to non-timber forest products vary from one aren to another. It is directly linked with the biological resources and species composition. For instance, the importance related to Kitul (Caryota urens), Wewal (Calamus spp) and resins in the fringe communities of the Adam's Peak Wilderness differ from those of Ritigala. In Ritigali Bee-honey, Calsiyambla (Diclitum ovoideum) and Bin-kohomba (Mimronia pismila) are the sources of income for the majority, whike in the Knuckles Range cardamom is the most favoured product.

Features related to non-timber forest products are complex, but the systems of human-forest interface is largely influenced by the sccio-wonomies related to NonTimber Forest Products (NTFPs). The scasonal patterns in the availability and phenological cycles of products maintain the scasonal variations in human contact. The gender specific patterns are very much related to the nature of the NTFP, their intended uses and the socialized relationships between men and women. The products entering the household maintenance systems are gathered more regularly by women and these include fuelwood, fcod, products used for porridge making and medicinal purposes and also raw materials for utensil making. The products of market and industrial importance are related to the cash economy of the households and tend to be influenced more by the external market cconomy than household subsistence neods.

Although the settlements are physically separated from the forests and expected to see a survival system detached from the forest, in practice, the land-based living depends either heavily or partly on the forest for support. Information on the cash generated from NTFPs has been gathered (exeluding the products used for household maintenance). Local communities as a group bencfiting from the NTFPs for income and subsistence in turn are engaged in forest management informally through their contacts. However, their geographical location is itself not sufficient cause for them to become involved. For instance, only $2 \%$ of the plantation communities of the Adam's Peak fringe has shown an interest to be formally involved in the management, while it was more than $68 \%$ in the south. In Ritigala, the primitive groups have expressed a unique and stronger interest than the others due to their feeling of inheritance from the forest. This implics that local communitics as beneficiaries want to be involved differently. Yet, they often do not see it as an indirect payment for the NTFPs because conservation interest includes their concems over service functions, and the spinitual, religious and cultural importance of the forest. 


\section{COMMUNITY ORGANIZATIONS}

The informally existing management systems are not recognized due to their lack of legal regulations. Yet, as has been explained by Berkes and Farvar (1988), "It is no accident that traditional resource management systems are often community basud". If local communities are to be taken as a means of solving the problems that the state has not been ablo to solve over the years, then their existing social systems or organisations, which can be formed by themselves, noed to be re-examined. Community management cannot be taken as a system under which frec access to forests could be offered. Sirnilarly, the current situation shows that community level organizations that are formod with the interest of being involved in forest management, together with the state agencies, are scarcs: Community organizations are important in strengthening the capacity to control individual interest that could be hamful, and also to facilitate mutual connections, interactions and consultation over the issues that arise.

In most cases, what we find in reality is that organizations do not bring members living in geographical areas together. It is difficult to have members with the same degree of interest and concern in one location, or along the fringe belt to a forest. However, a certain degree of common interest to protect the forest as part of their survival system and to control the external pressures on the forest exists, particularly regarding the destructive uses like timber harvesting. Strong social regulations exist among the communities that claim to be the descendants of hunting and gathering groups. For instance, in Ritigala, Kiriyagaswewa, Muriyakadawala, Kaluebe and Moragoda the concern over the forest as an inherited superior resource, and the practice of group gathering and sharing forest products, and also respect for group consensus with regard to the activitics related to forest resource use, are the remnants of strong social regulations that have long been operating (Wickramasinghe, 1995b).

In other areas not only are such social regulations lacking, but involvement also takes place where individual and family interests are concemed. In the devolution of management responsibilities it is important to ensure that individual interests are excluded, that disputes are managed within the communitics, that they exereise the power to control all external interruptions and are consulted in all legal and practical matters. Although along all forest fringes local communities are involved in using forest resources, the interest to promote management oryanizations is lacking in some pockets. The situation in the fringe characterized by plantation agriculture reveals that strong non-forest survival systems are poorly connected with the forest. Here, the creation of organizations is impossible.

Under what conditions the communities involved in forest management could informally be empowered with a task to be shared with the state is important. Their common interest is the local initiative to be promoted by formulating regulations that can be accepted. The economic importance of the forest as well as the practical feasibility for them to booome managers of the forest cannot be the vague end of state 
Whchramasinghe

involvement. Pre-examination of social regulations that could be invited of introduced and consultative connections between local communitics and state agencies in introducing mechanism for sharing the power of management require a large number of strategic and community based rescarch. From the practical perspective the status that could empower local communities should not lead to a tragedy of the forests. Interest must be to make use of the social system that exists in a better position to buffer the forest from external pressures while recognizing the benefits that they get in kind out of the forest. As in the case of state agencies, the local communities will be responsible for the future of the forests that are exposed to many deleterious processes. The level of state control differs from one area to another, because as in the case of the Knuckles Range there seems to be a greater role for the state to enforce legislation regarding forest cultivation, while working with the communitics to promote non-forest based support systems. In most cases the manipulated state administration systems, the "Grama Niladari Divisions" do not tally with the traditional viliage identities. So the potential for using the administrative framework is minimal. The interactive social-systems that are often in line with traditional villages are more appropriate:

\section{CONCLUSIONS}

The rationales for empowering local communities to manage local forests are numerous, and are directly related to their locational advantages and their ability to act as a social buffer. In addition, the restoration of indigenous knowledge through community participation is essential for developing management strategies and to improve local economies with the self confidenoe of the people, Unless such an effort is made, management policies will be vulnerable to political changes and affluence,

There are two major areas requiring the attention if community management systems are to be executed. One area deals with the question of property rights. This is not confined to the rights of communities to the forests, but more strongly what they are to share as partners with the state. The other issue is related to community involvement because, in practice, the communities are not treated as equal partners, nor in most cases as potential contributors within the power hicrarchy.

The willingness of the state sectors to accept the cconomic and cultural values of indigenous forest management systems as suitable strategies has so far not been a topic for discussion. How local communities and the state sector could develop a collaborative mechanism has so far been neglected. Not only dos this require the legitimizing of customary rights but also the recognition of indigenous knowledge and the more strongly required negotiations and lobbying which has not taken place so far.

The non-forest policies impinging on the sustainable management of forest resources also noed urgent attention. As long as the adjoining non-forest lands induce pressure 
on the forest its survival carnot be expected, Non-forest lands must be managed as an alternative source for forest products, at least to cater for timber, medicinal and raw materials. The incentives for delivering non-forest activitics should not be the disincentives for forest management.

No formal and legitimized blanket recommendations can be made with regard to community involvement because this depends on the interest of local communities and how the state and communities reach the terms involved. The first step in this process is to learn and/or form local institutions with the interests of joining the state effort. The existing social systems show some degret of cohesiveness in terms of reciprocity, sharing, communication and social interactions. However, the prevailing social hierarchy in many communities has resulted in fragmenting the unity, and in these cases institutional building must be initiated. In order to affirm equity among those who are involved in the management, suitable mechanisms need to be introduced through ficld investigation and communication. The social regulation that could be enforced by local institutions cannot be enforced under existing state agencies, so, it is neccssary to use the existing social systems that are culturally. sensitive. Local communitics could provide solutions to current problems only if the state is willing to made adjustments to suit local situations.

\section{REFERENCES}

Berkes, F. and Farvar, M.T. (1988). Introduction and overview, in Common property resources: Ecology and community based sustainable development, Berkes, F, (Ed), London: Belhaven Press 1-17.

D'Silva. E.H. and Kariyawasam, D. (Eds.) (1995). Energing Issues in Forest Management for Sustainable Development in South Asia, Manila: Asian Development Bank.

FSMP (1995). Sri Lanka Fonestry Sector Master Plan, Forestry Planning Unit, Ministry of Agriculture, Lands and Forestry, 82, Rajamalwatta Road, Battaramulla, Sri Lanka

Gilmour, D.A. (1988). Not seeing the trices for the forcst A re-appraisal of the deforestation crisis in two hill districts of Nepal, Mountain Reseurch and Development. 8 (4): $343-350$

Gilmour, D.A. and Nurse, M. (1991). Farmer initiatives in increasing tree cover in central Nepal, Mountain Research and Development. 11 (4): 329-337.

Gilmour, D,A. (1995). Conservation and development: Seeking the linkages, In Community development and consenation of forest biodiversity through community forestry. H. Wood, M. McDaniel and Wamer, K. (Eds.). Bangkok: RECOFTC. 7-20,

IUCN/UNEP/WWF (1980). World Conservation Strategy: Living Resources Consenation for Ststainable development, Gland, Switzeriand: IUCN, UNEP, WWF

Saxcta, N.C. (1995). Forests People \& Profit, New Delhi: Diamond Printers 
WCED (1987). Our Common Future, World Commission on Environment and Development, Oxford University Press.

Wickramasinghe, Anoja (1990). Social and ccononic aspects dealing with the conscrvation and manikgement of natural forests in Sri Lanka, In Harmony with Nafure, Yap Son Kheong and Lee Su Win (Eds.). Kuala Lumpur 592-607.

Wickramasinghe, Anoja (1994). Perceptions and Knowledge of Local Communities for a Rapid Appraisal of Biodiversity, Paper presented at the IUFRO Forest Biodiversity Symposiam on Measuring and Monitoring Biodiversity in Tropical and Temperate Forests, August 28 - 8th September, Chiang Mai, Thailand.

Wickramasinghe, Anoja (1995a). People and the forest; Mandgement of the Adam's Peak Wilderness, Sri Lanka Forest Department.

Wickramasinghe, Anoja (1995b). Anthropogenics related to forcst management in Sri Lanka, Paper presented at the Sri Lanka Association for the Advancement of Science (SLAAS), (7th October, 1995).

Wickramasinghe, Anoja (1995c). A re-examination of prospects for integrating conservation of biodiversity into the development of forest buffers through community participation, In Community development and consenalion of forest biodiversify through community forestry, $\mathrm{H}$. Wood, M. McDanicl and Warner, K. (Eds). Bangkok: RECOFTC. 77-100, 